care, but he had made it over to his collearue, and asked me to send it back to St. Mary's when well of the fever, as Mr. Ewart was anxious to perform lithotomy. I replied "that personally I did not care who had the stone, but I would speak to my colleague, Mr. T. Jones, and I had no doubt if I did so he would waive any claim he might have." On another occasion, when Dr. Lloyd Roberts was in my house about another matter, I suddenly remembered the case, and said, "Ob, that stone case is doing well ; I must remember to see about him for you." I also told the boy (aged ten) that he might tell his mother that when he was no longer infectious she might take him back to St. Mary's. Now, about this time it happened that $\mathrm{Mr}$. Jones, in consequence of the illness of a relation, was a good deal from home, and was much taken up by other pressing engagements; I seldom saw him, and, most unfortunately, it entirely slipped my memory to set matters straight about the stone. A few weeks afterwards I left home at a short notice, and unluckily the operation was performed by my colleague in complete ignorance of my interview with Dr. Lloyd Roberts. On my return I was exceedingly annoyed with myself for not having left special directions concerning the case. I took an early oppor tunity of explaining to Dr. Lloyd Roberts what had happened, and expressed my great regret that I should have been so forgetful in the matter, and how I would willingly take upon myself the blame of what had occurred. I must say, Sir, that after thus expressing my regret I never for a moment expected to hear any more of the matter. I was surprised to hear that it had become a burning question of " hospital etiquette " and still more astonished was I to read that Mr. Ewart had "learnt that from the first the Pendlebury staff never meant the boy to return to St. Mary's." Let me say at once this is untrue. The case was admitted under my care, and except on the occasion just referred to I never spoke to my colleagues on the subject. I am unaware of any decision affecting its destiny, and had I not forgotten to speak to my colleague I do not doubt it would have returned to St. Mary's.

Having thus apologised to Dr. Lloyd Roberts, to whom the case belonged, and who had specially called on me on the subject, what more, Sir, could I do? I am sorry Mr. Ewart was disappointed and annoyed, but if he is still angry I cannot help it ; and if he still impute bad faith to me, I have no more apologies to make, and will willingly leave it to the "seritiments of the profession" to decide, to whom the "discourteous" and "ungenerous" apply. I remain, Sir, yours, \&c.,

Manchester, Sept. 21st, 1880. HENRY ASHBY.

** We are glad to receive this explanation, which will, of course, close the matter.-ED. L.

\section{"NEW INSTRUMENT FOR CLEFT PALATE."} To the Editor of THE LANCET.

SIR,-Having read Mr. Furlong's description of his needle on the shuttle principle in THE LANCET of September 18th, I hasten to concede to him whatever credit may be due for priority of invention over the instrument on the same prin ciple devised by me, a description of which appeared in THE LANCET of July 24th. I would also express my appreciation of the additional miniature blade for isolating the tissues during perforation, which is part of his instrument, and is a deficiency in my own which I was even now attempting to supply.

At the same time it is due to myself to state that, previously to forwarding my communication, I had taken every pains to ascertain whether the idea as it occurred to me had been already carried out. It was only after failing to discover any knowledge of such an instrument either on the part of those surgeons to whom I showed mine, or of the instrument makers, and after a vain search through every accessible record of surgical appliances, that I forwarded it for publication. This general ignorance respecting the existence of Mr. Furlong's invention cannot be wondered at, as he states "there is no published account" of it. I think, therefore, Mr. Furlong will have no cause to regret the step I took in calling attention to a needle on the shuttle principle, I being a bsolutely ignorant of his invention-inasmuch as my so doing has served to rescue his from the undeserved obliviou into which he had suffered it to lapse.

Respecting the points of divergence between the two in- struments, whether the blades should be scissors or forceps, the method of fixing the needle on the one blade and of clamping it in the other, these are matters of detail concerning the respective advantages of which experience alone will enable a correct estimate to be formed. What is of more im. portance to know, and which Mr. Furlong's experience goes to prove, is that the irksomeness of cleft palate operations can be lessened by the use of an instrument which his in. genuity had already devised when I was labouring to attain it. Had it not been for Mr. Furlong's reservation of his skill I should have been spared this labour, and your columns the tedium of a personal explanation.

london, Sept. 20th.

$$
\text { I remain, Sir, yours, \&c., }
$$

\section{A TONGUE - DEPRESSOR. \\ To the Editor of THE LANCET.}

SIR,-In bringing forward the accompanying pattern of a tongue-depressor, I do not claim for it any undue amount of importance; but as it is a little instrument in frequent requisition, I have devised the present form, and, finding it so convenient after twelve months' use, send you a pattern for publication.

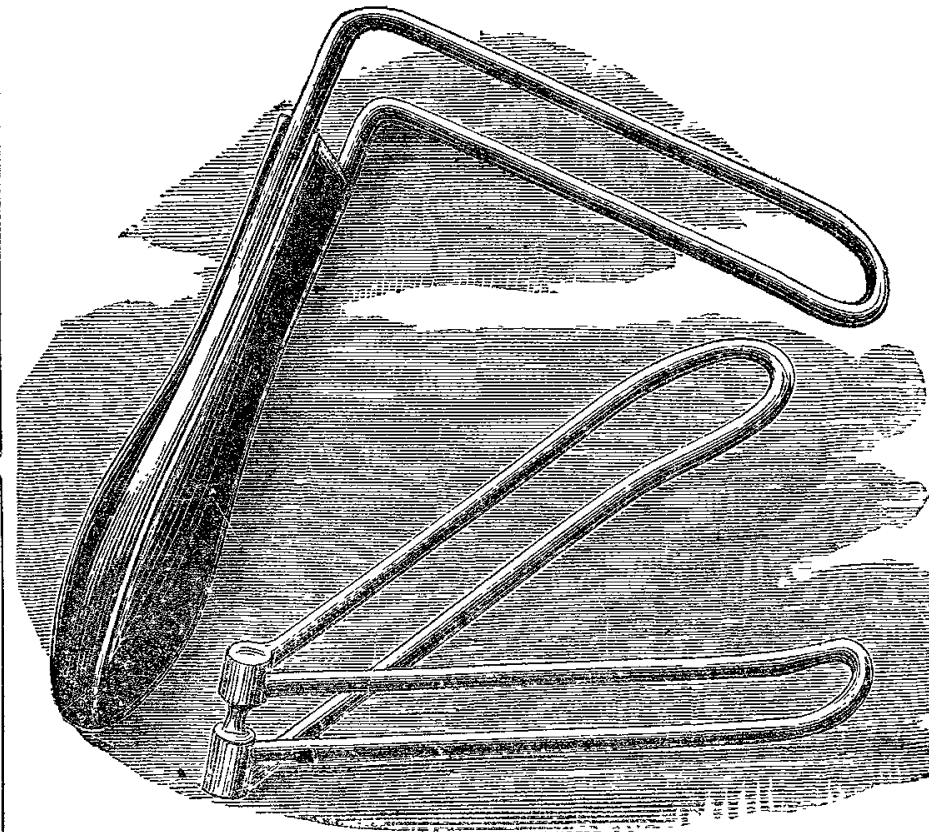

The advantages it possesses over the ordinary clumsy instrument are, that the tendency to retching is lessened by the smaller surface of metal inserted in to the mouth. The tongue is not concealed by it; and with patients who have the knack of "hawing up" the tongue, the sides of the in strument, which press into its substance, admit of a view of the fauces, which would be impossible with the old instrument.

I have found it useful in the examination of the irritable throat of phthisis, where the ordinary mass of metal introduced into the mouth renders a view impossible by reason of the discomfort and irritation produced. It is light and portable, of much less cost than the ordinary form, and easily cleaned.

The woodcut represents one pattern with a handle for hospital use, and the other jointed for the pocket. These have been made for me by Mr. Goode, of Praed-street. I am, Sir, your obedient servant,

ALFRED WISE, M.D.,

Sutherland-gardens, W., Visiting Physician to the Infirmary for September, 1880 . $\quad$ Consumption, Margaret-street.

\section{DIPHTHERIA.}

\section{To the Editor of THE LANCET.}

SrR,-In the spring of last year (1879) I attended during an outbreak of diphtheria a family consisting of five persons - viz., father, mother, two little children, and a young servant girl.

The servant showed symptoms of the disease on March $22 n d$; it ran a favourable course, and she was convalescent on the 29 th. 